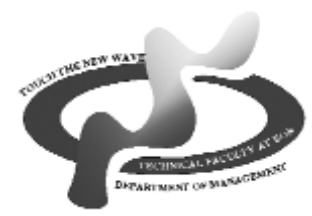

www.sjm06.com
Serbian

Journal

of

Management

\title{
MODELING THE INFLUENCE OF EFQM CRITERIA ON EMPLOYEES SATISFACTION AND LOYALTY IN TRANSITION ECONOMY: THE STUDY OF BANKING SECTOR IN SERBIA
}

\author{
Marija Savić*, Predrag Djordjević, Djordje Nikolić, \\ Ivan Mihajlović and Živan Živković \\ University of Belgrade, Technical Faculty in Bor \\ Vojske Jugoslavije 12, Bor, Serbia
}

(Received 12 September 2013; accepted 15 December 2013)

\begin{abstract}
The paper presents the results of empirical research on the effects of some criteria of the EFQM excellence model on satisfaction and loyalty of the employees in the banking sector in Serbia. All but one of the hypotheses in the defined model were proven by statistical evaluation of empirical results. The one which could not be proven is the hypothesis of a positive impact of the organization's relationship toward security and society on the business result, which makes specificity of transitional economic conditions in which the studied banking sector operates. Statistical analysis was performed using V.16 LISREL software package where statistical significances of the studied set were defined together with $b$ and $t$ values of the defined paths in the defined model. Researches have shown that criteria of EFQM excellence model can be used to develop and improve the functioning of the banking system in Serbia and develop the TQM practice.
\end{abstract}

Keywords: EFQM model, criteria, banks, satisfaction of employees, loyalty of employees, LISREL

\section{INTRODUCTION}

The EFQM excellence model involves nine criterions and the relative importance of each criterion is indicated by the criterion weight structure (EFQM, 2005). Research on the weight structure has been limited and this is problematic, regarding the use of the model, because it raises the question of whether or not it makes any sense to compare companies according to an arbitrary weight structure, which has never been empirically tested (Tutuncu \& Kucukusta, 2007; Lam et al., 2011). EFQM excellence

\footnotetext{
*Corresponding author: msavic@tf.bor.ac.rs
}

DOI: $10.5937 /$ sjm 9-4972 
model criteria provide a framework for the encouragement and development of many elements of TQM practice in organizations. Some of the elements are the complementary with the Six Sigma (Campatelli et al., 2011), complementarity with organizational commitment (Tutuncu \& Kucukusta, 2007), work motivation (Al-Zoubi, 2012) and the resource - based view (Balbastre-Benavent \& Canet-Giner, 2011).

Starting from the crucial fact that the service organizations, such as Banks, mainly rely on their employees who maintain relationships with clients and also generate revenue, it can be concluded that satisfaction and loyalty of employees can greatly affect the quality of services of any bank. The results of investigations of application of the elements of TQM practice, or excellence model criteria on business results, or satisfaction and loyalty of employees rarely occur in the literature, although they should present fundamentals for good performance of each bank (Al-Shobaki et al., 2010; Beikzard et al., 2012; Spasojević-Brkić \& Putnik., 2013; Marimon et al., 2012). Therefore, in this paper, the focus of the research is directed toward defining the model of impact by implementing the criteria of the EFQM excellence model on the loyalty and satisfaction of the employees working in banks in Serbia.

\section{THEORETICAL HYPOTHESES AND DEFINITION}

BASE, MODEL

The reason for the implementation of the EFQM excellence model criteria in this study is that it presents a framework of selfevaluation, which allows each organization to determinate its strengths, and the areas where further improvements can be made (Chen et al., 2012). Various recommendations can be found in the literature considering using this excellence model criteria to identify and solve management problems (Balbastre-Benavent \& Canet-Giner, 2011), while on the other hand, many authors point out some major problems in organizations during the implementation of the EFQM model and with attempts to measure their performances (Lusar et al., 2009; Safari et al., 2012). However, the results which favor the use of this criterion are of significantly higher level compared to the potential problems of implementation of the EFQM model.

\subsection{Leadership}

Commitment of the top management to the achievement of quality objectives must be clearly visible, permanent and present at all levels of the organization. The tasks of top management are reflected in the promotion of different types of knowledge, encouraging activeness and innovation with employees, which are key factors of the business success (Zelnik et al., 2012). Also, top managers as leaders must present a guiding light in the implementing of the TQM process, which is achieved through the definition of quality objectives and treatment of quality as strategic planning (Soltani et al., 2005; Candido \& Santos, 2011). The focus of top managers on employees, material and financial resources as well as development of policy and strategy must be a priority for any organization (Soltani et al., 2005). Lack of support from top management is a critical reason why many institutions haven't had success in implementing TQM (Chang et al., 2010). The role of top managers is to manage all vital processes which are realized in the 
company, especially in companies with TQM practice based on the process principle (Chang et al., 2010; Doeleman et al., 2012). These facts led to the defining of the following hypotheses:

$H_{1} a$ - The manager's leadership in the discussed banking sector in Serbia has a positive impact on human resources.

$H_{1} b$ - The manager's leadership in the discussed banking sector in Serbia has a positive impact on development of the policy and strategy.

$H_{1} c$ - The manager's leadership in the discussed banking sector in Serbia has a positive impact on the processes management in the organization.

\subsection{Policy and strategy}

Policy is a method of conducting business or coexistent set of principles which represent a guideline for the execution of business activities of the organization. To achieve defined objectives, organization conducts strategic planning that determines the direction in which the organization needs to move, which allows organizations to direct their primary efforts towards an established goal (Candido \& Santos, 2011). In addition, strategic planning provides understanding and managing in the complex business environment and in the high level of uncertainty in the business environment. Developing relationships with clients and suppliers and creating partnerships represents a good practice of successful companies (Ishaq, 2012). Therefore, the following hypotheses can be defined:

$\mathrm{H}_{2} \mathrm{a}$-Policy and strategy have a positive impact on the client relationships.

$\mathrm{H}_{2} \mathrm{~b}-$ Policy and strategy have a positive impact on the relationship with suppliers.
$\mathrm{H}_{2} \mathrm{C}$ - Policy and strategy have a positive impact on the security and society.

\subsection{Human resource management}

According to the criteria of the EFQM excellence model, successful organizations manage, promote and develop the potential of their employees at the individual, team and organizational level (EFQM, 2005).

People are the ones who achieve the occurrence of the quality in the company. The best way to achieve success in the company is continuous work with people, their training and encouragement at all levels (Tari et al., 2007). Assessment and academic models, which are built into the activities related to human resources, have led to this idea, so it can be said that human resources are necessary for the development of TQM practice. Employees need training, thus they will be able to identify and solve problems, improve work methods and take responsibility for the quality (Lam et al., 2012). The training must include human and technical aspects (Omachonu \& Ross, 2004). Therefore, the following hypothesis can be proposed:

$\mathrm{H}_{3}$ - Human resource management has a positive impact on the business result.

\subsection{Relationship with clients}

Commitment to the TQM in the company includes cooperation with clients and suppliers by creating a unique supply chain (van Donk \& van Der Vaart, 2005) in order to shift trade relations into the partnership relations. Customer satisfaction is the most important element of the functioning of TQM, which led to the development of different models of consumer satisfaction 
(Heras-Saizarbitoria et al., 2012). Considering that customers (clients) determine the level of quality which is realized in the company, as defined by the ISO 9000 standard (Corbett et al., 2005), following hypothesis can be defined:

$\mathrm{H}_{4}$ - The relationship between the organization and the clients has a positive effect on the business results.

\subsection{Relationship with suppliers}

Improvement of relations with suppliers improves the process performance of the company, thus improving performances of both customers and suppliers. In this respect, materials purchased from suppliers must meet the customer's specifications and quality standards, which positively affect the applicability of the process and thus the management of quality improvement process. This opinion suggests that procurement management can have a positive influence on the management of the quality improvement process (Kaynak, 2003; Safari et al., 2012). Based on the above considerations, considering the impact of relationship with suppliers and management of key processes in considered banks in Serbia, the following hypothesis can be defined:

$H_{5}-$ Relationships with suppliers have a positive impact on the business results.

\subsection{The attitude towards security and society}

Security is a state in which balanced physical, spiritual and physical survival of the individual and the community is assured, in relation to other individuals in the community and nature. Management care for their employees is a strong motivating factor, because it creates security for employees and allows employees to devote their attention to their work, which in some way presents psychological contract between the employees and the management of the company. Sometimes while recognizing social, psychological and other problems of the employees, required changes in the organization of work are required (ShengHsun, 2007). Employee satisfaction with the care and relationship of their supervisors creates psychological security and loyalty to the company (Chen et al., 2012), which is crucial for the development strategy of Human Resource Management (HRM) in the companies, which allows defining the following hypothesis:

$H_{6}-$ Relationships of the organization with the security and society have a positive impact on the business result.

\subsection{Process management}

The structure of the EFQM excellence model suggests that the process management presents the relationship between other implemented factors of possibilities and results (EFQM, 2005). The process approach of quality management implies the development of a system of continuous quality improvement (Al-Zoubi, 2012), in order to achieve better operating performance and greater employee loyalty (Omachonu \& Ross, 2004). This approach allows the proposal of the following hypothesis:

$\mathrm{H}_{7}$ - Process management has a positive impact on the business result.

\subsection{The business result}

The business result of the company is measured by the results realized on the 
market. If the financial results are good, meeting the hierarchy of employees needs is achieved to a significant extent, which increases employees satisfaction (Maslow, 1943). Numerous studies show that motivational factors, arising from the needs of the people, change over the time and have certain characteristics at the beginning of the new millennium (Latham \& Ernst, 2006; Chen et al., 2012). These facts indicate that the following hypothesis can be defined:

$H_{8}-$ The business result positively effects the satisfaction of employees.

\subsection{Satisfaction of employees}

In an effort to provide employees with high levels of performance, companies are trying to establish a positive attitude toward job satisfaction and organizational learning. In developing the "knowledge economy", employee satisfaction and loyalty takes a critical position (Marimon et al., 2012). Many empirical studies have shown that employee satisfaction has a positive influence on the organizational capability and loyalty (Mak \& Sockel, 2001), and negative influence on the mobility of workers in the form of leavening and switching the firms. These facts enable the definition of the following hypothesis:

$H_{9}$ - Satisfaction of employees positively affects their loyalty.

Based on the theoretical considerations of the basic criteria of the EFQM model of excellence in the field of opportunities and in the field of results, for the studied service companies - Serbian banks, which operate under conditions of a transition economy, a theoretical hypothetical model of the impact of the criteria of the EFQM model of excellence on the satisfaction and loyalty of employees, can be defined (Figure 1).

\section{RESEARCH METHODOLOGY}

For the research, whose results are presented in this paper, a questionnaire

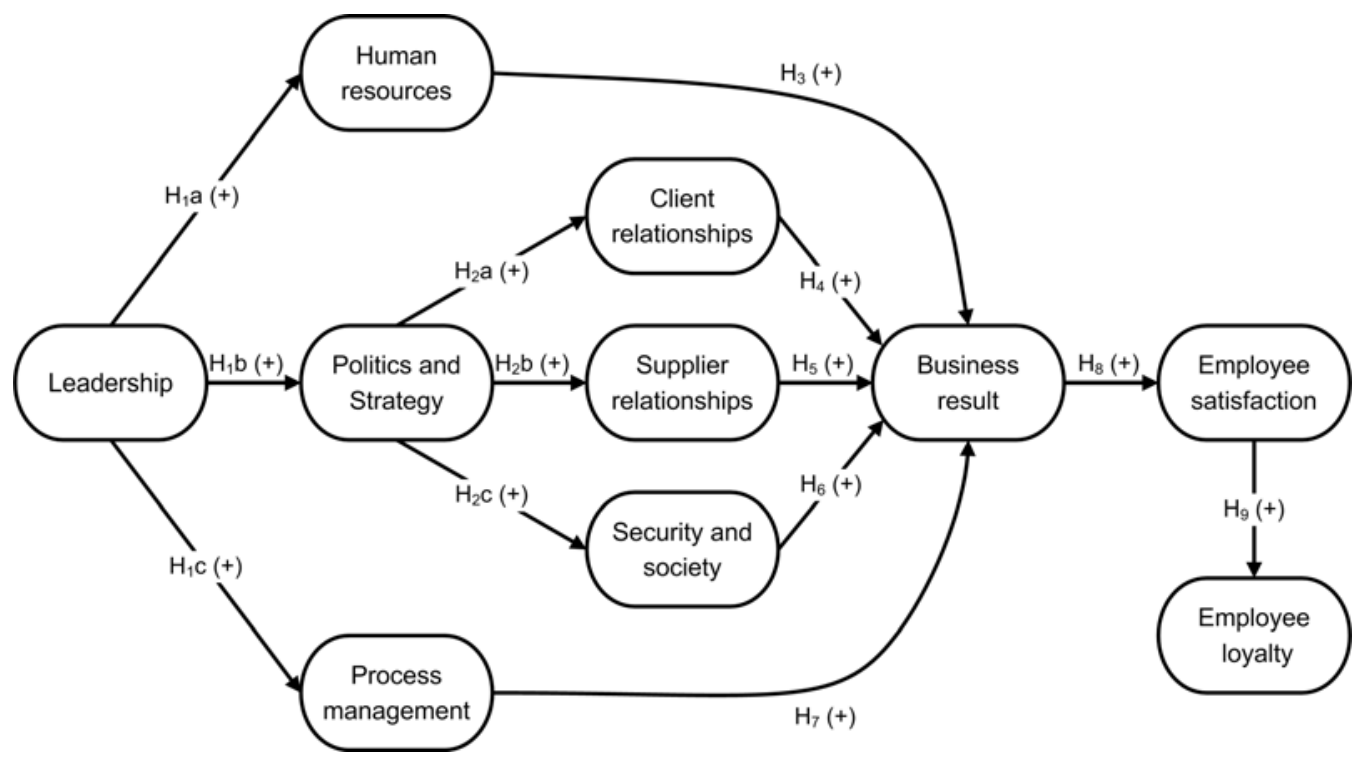

Figure 1. A conceptual model of the impact of some criteria of EFQM excellence model on the satisfaction and loyalty of employees in the banking sector in Serbia 
(Appendix A) survey was used, which was sent to 335 randomly selected bank branches of the 35 subsidiaries of domestic and foreign banks operating in Serbia. Questions in the questionnaire were combined using the results of previous researches (Kaynak, 2003). Total number of questions in the survey amounted to 42, divided into 10 groups. After consultations and visits to bank branches, 678 correctly completed questionnaires from 156 bank branches were obtained, which presents a response of $46.56 \%$ of the companies. This level of response is much higher than in other similar studies (Kaynak, 2003), in which the response was less than 20\%. Demographic characteristics of the investigated population are shown in Table 1.

Multivariate test of the levels of significance for main effects between groups of variables: workplace, age and years of service was carried out using four multivariate tests: Pillai's Trace, Wilks Lambda, Hotelling's Trace and Roy's Largest Root, which resulted in high values for the level of significance of 0.000 which indicates that there is a difference in responses in relation to the workplace, age, seniority, therefore the results can be considered acceptable (Ho, 2006).

Likert's five-point scale (1 - completely disagree, 2 - disagree, 3 - undecided, 4 agree and 5 - completely agree) was used for the research whose results are presented in this paper. This methodology has been used in many previous studied (Kaynak, 2003; Tari et al., 2007), which justifies the validity of the methodology.

\section{RESULTS AND DISCUSSION}

Validation of the theoretical model defined in Figure 1 was conducted by using the software packages SPSS v. 18 and LISREL (Linear Structural Relationship) v. 16. For the empirical validation of the hypothetical model, Figure 1, in this paper, the SEM (Structural Equation Modeling) methodology was used. In the statistical analysis of the validation of the defined models, firstly one-dimensionality was

Table 1. Demographic characteristics of the sample

\begin{tabular}{|l|l|c|}
\hline \multirow{2}{*}{$\begin{array}{l}\text { Demographic } \\
\text { variable }\end{array}$} & \multicolumn{2}{|c|}{ Structure of the sample } \\
\cline { 2 - 3 } Workplace & Category & Share (\%) \\
\hline & Administration & 13 \\
& Marketing and Development sector & 3 \\
& Providing teller services & 37 \\
& Management structure & 29 \\
& Other & 18 \\
\hline \multirow{5}{*}{ Age structure of } & Less than 20 years & 0 \\
respondents & 20-30 years & 10 \\
& 30-40 years & 24 \\
& 40-50 years & 28 \\
& Over 50 years & 38 \\
\hline \multirow{5}{*}{ Years of service } & Up to a year & 0 \\
& 3-5 years & 8 \\
& 5-10 years & 18 \\
& 10-20 years & 55 \\
\hline
\end{tabular}


confirmed using factor analysis (PCA), across all 10 groups of latent variables in the considered model. The values which were obtained by factor analysis are shown in Table 2. To ensure the reliability and validity of the research model a control measurement model was defined on which confirmatory factor analysis (CFA) was performed. The results obtained in Table 2 for CFA show that in all cases t-values were much greater than 2 with significance level $\mathrm{p}<0.05$ and $\mathrm{p}<0.01$, therefore CFA analysis confirmed the good fit of the control model, which practically verifies that 42 defined variables describe, in a reliable way, the ten latent class variables, defined in the research model (Figure 1) (Ho, 2006).

Consistency of variables defined in the framework of latent classes, in the research model, was measured by the size of Cronbach's alpha coefficient (Cronbach, 1951). Obtained values of the Crombach's alpha, were greater than 0.7 , for each group of questions (Table 2), show good consistency of individual variables within the 10 defined latent groups of variables of the tested model. Cronbach's alpha value for the whole population is 0.96 , so obtained data can be considered reliable for testing of the proposed model.

To test the validity of the conceptual model defined in Figure 1, software package LISREL v.16 was used for statistical data analysis by utilizing the Structural Equation Modeling method, considering that the statistical reliability of the data for the model validation is satisfactory.

Firstly, the values of required indicators were determined, which determine whether the proposed model adequately fits the input data. The results of the analyzed fitting indicators are shown in Table 3.
The obtained values of the considered indicators of fitting indicate a satisfactory level of fitting in the proposed model, which suggests that the regression coefficients of the characteristic structural paths can be calculated in the defined theoretical model in Figure 1, with the satisfactory accuracy.

By using LISREL v.16 the coefficients of regressions - paths were determined (correlations between the defined latent class variables in the model, which is shown in Figure 1). Results are presented in Figure 2. The results from the Figure 2 indicate that all the hypotheses of the defined model have positive values of path coefficients, except the hypothesis $\mathrm{H}_{6}$, which is characterized by a correlation coefficient of -0.081 with statistical significance of $\mathrm{p}=0.067$ and $\mathrm{t}=$ 1.48. Before making a final decision on acceptance of the model, it is necessary to determine the $\mathrm{t}$ - values of all the hypotheses, in order to determine the statistical significance of obtained results. Calculated $\mathrm{t}$ - values are shown in Figure 2 (values in parentheses).

Obtained results have values which are in all cases greater than 2 (except the hypothesis $\mathrm{H}_{6}$ ) with statistical significance $\mathrm{p}<0.001$ to $\mathrm{p}<0.05$. In this way, the positive correlation between the defined latent variables is further confirmed, within the theoretical model which is defined in the Figure 1, except in the case of hypothesis $\mathrm{H}_{6}$. Based on these results, it is obvious that the employees in the banking sector in Serbia have good working conditions and these are implied in such a workplace, where there is no sense of philanthropic responsibility of banks towards the society. Cooperation between the banks and the society was perceived by the bank employees as an expense rather than an investment, and hence 
Table 2. The results of the factor analysis and the CFA analysis of the investigated model

\begin{tabular}{|c|c|c|c|c|c|c|}
\hline \multirow[b]{3}{*}{ Question group } & \multirow{3}{*}{$\begin{array}{l}\text { Considered } \\
\text { variable }\end{array}$} & \multirow{2}{*}{\multicolumn{2}{|c|}{$\begin{array}{c}\text { Factor analysis (EFA) } \\
\text { PCA }\end{array}$}} & \multicolumn{3}{|c|}{$\begin{array}{c}\text { Confirmatory factor analysis } \\
\text { (CFA) }\end{array}$} \\
\hline & & & & \multirow{2}{*}{$\begin{array}{l}\text { Reliability } \\
\begin{array}{c}\text { Cronbach's } \\
\text { alpha }\end{array}\end{array}$} & \multicolumn{2}{|c|}{ Convergent validity } \\
\hline & & $\begin{array}{c}\text { \% of variance } \\
\text { explained by one- } \\
\text { dimensional } \\
\text { factor }\end{array}$ & $\begin{array}{r}\text { Factor } \\
\text { loading }\end{array}$ & & $\begin{array}{l}\text { Factor } \\
\text { loading }\end{array}$ & $\begin{array}{c}\mathbf{t}- \\
\text { statistics }\end{array}$ \\
\hline Leadership (L) & $\begin{array}{l}\text { L1 } \\
\text { L2 } \\
\text { L3 } \\
\text { L4 } \\
\text { L5 }\end{array}$ & 57.343 & $\begin{array}{l}0.811 \\
0.804 \\
0.815 \\
0.549 \\
0.773\end{array}$ & 0.809 & $\begin{array}{l}0.730 \\
0.703 \\
0.764 \\
0.492 \\
0.732 \\
\end{array}$ & $\begin{array}{c}10.640^{* *} \\
10.286^{* *} \\
11.487^{* *} \\
7.309^{*} \\
10.560^{* *}\end{array}$ \\
\hline $\begin{array}{c}\text { Human } \\
\text { resources (HR) }\end{array}$ & $\begin{array}{l}\text { HR1 } \\
\text { HR2 } \\
\text { HR3 } \\
\text { HR4 } \\
\text { HR5 }\end{array}$ & 62.392 & $\begin{array}{l}0.761 \\
0.806 \\
0.839 \\
0.816 \\
0.721\end{array}$ & 0.842 & $\begin{array}{l}0.736 \\
0.717 \\
0.763 \\
0.739 \\
0.688\end{array}$ & $\begin{array}{l}10.204^{\text {** }} \\
10.528^{\text {** }} \\
11.025^{\text {** }} \\
10.540^{\text {** }} \\
10.056^{\text {** }}\end{array}$ \\
\hline $\begin{array}{c}\text { Policy and } \\
\text { Strategy (PS) }\end{array}$ & $\begin{array}{l}\text { PS1 } \\
\text { PS2 } \\
\text { PS3 } \\
\text { PS4 } \\
\text { PS5 } \\
\end{array}$ & 59.937 & $\begin{array}{l}0.818 \\
0.742 \\
0.772 \\
0.742 \\
0.795 \\
\end{array}$ & 0.923 & $\begin{array}{l}0.731 \\
0.675 \\
0.669 \\
0.710 \\
0.746\end{array}$ & $\begin{array}{l}11.180^{\text {** }} \\
10.091^{\text {** }} \\
10.291^{\text {** }} \\
10.767^{\text {** }} \\
11.338^{\text {** }}\end{array}$ \\
\hline $\begin{array}{c}\text { Supplier } \\
\text { relationships } \\
\text { (SR) }\end{array}$ & $\begin{array}{l}\text { SR1 } \\
\text { SR2 } \\
\text { SR3 }\end{array}$ & 79.236 & $\begin{array}{l}0.881 \\
0.901 \\
0.889\end{array}$ & 0.868 & $\begin{array}{l}0.787 \\
0.875 \\
0.823\end{array}$ & $\begin{array}{l}12.540^{* *} \\
14.059^{* *} \\
13.656^{* *}\end{array}$ \\
\hline $\begin{array}{c}\text { Process } \\
\text { Management } \\
(\text { PM) }\end{array}$ & $\begin{array}{l}\text { PM1 } \\
\text { PM2 } \\
\text { PM3 } \\
\text { PM4 }\end{array}$ & 68.918 & $\begin{array}{l}0.859 \\
0.904 \\
0.844 \\
0.700\end{array}$ & 0.846 & $\begin{array}{l}0.891 \\
0.899 \\
0.722 \\
0.545\end{array}$ & $\begin{array}{l}16.789^{* *} \\
20.331^{* *} \\
12.868^{* *} \\
8.780^{* *}\end{array}$ \\
\hline $\begin{array}{c}\text { Client } \\
\text { relationships } \\
(\mathbf{C R})\end{array}$ & $\begin{array}{l}\text { CR1 } \\
\text { CR2 } \\
\text { CR3 } \\
\text { CR4 }\end{array}$ & 78.187 & $\begin{array}{l}0.859 \\
0.903 \\
0.888 \\
0.887 \\
\end{array}$ & 0.905 & $\begin{array}{l}0.795 \\
0.873 \\
0.853 \\
0.848 \\
\end{array}$ & $\begin{array}{l}12.985^{* *} \\
15.497^{* *} \\
14.646^{* *} \\
14.794^{* *}\end{array}$ \\
\hline $\begin{array}{l}\text { Security and } \\
\text { society (SS) }\end{array}$ & $\begin{array}{l}\text { SS1 } \\
\text { SS2 } \\
\text { SS3 } \\
\end{array}$ & 73.067 & $\begin{array}{l}0.894 \\
0.869 \\
0.798 \\
\end{array}$ & 0.814 & $\begin{array}{l}0.863 \\
0.803 \\
0.665 \\
\end{array}$ & $\begin{array}{l}14.027^{* *} \\
13.295^{* *} \\
10.614^{* *}\end{array}$ \\
\hline $\begin{array}{c}\text { Business Results } \\
\text { (BR) }\end{array}$ & $\begin{array}{l}\text { BR1 } \\
\text { BR2 } \\
\text { BR3 } \\
\text { BR4 } \\
\text { BR5 }\end{array}$ & 78.677 & $\begin{array}{l}0.752 \\
0.931 \\
0.939 \\
0.903 \\
0.897\end{array}$ & 0.930 & $\begin{array}{l}0.682 \\
0.934 \\
0.948 \\
0.857 \\
0.848 \\
\end{array}$ & $\begin{array}{c}8.565^{*} \\
13.445^{* *} \\
13.494^{* *} \\
12.298^{* *} \\
12.194^{* *}\end{array}$ \\
\hline $\begin{array}{l}\text { Employee } \\
\text { satisfaction } \\
\text { (ES) }\end{array}$ & $\begin{array}{l}\text { ES1 } \\
\text { ES2 } \\
\text { ES3 } \\
\text { ES4 }\end{array}$ & 61.320 & $\begin{array}{l}0.523 \\
0.844 \\
0.858 \\
0.855 \\
\end{array}$ & 0.784 & $\begin{array}{l}0.367 \\
0.720 \\
0.795 \\
0.874 \\
\end{array}$ & $\begin{array}{l}2.895^{*} \\
5.384^{* *} \\
5.352^{* *} \\
5.354^{* *}\end{array}$ \\
\hline $\begin{array}{l}\text { Employee loyalty } \\
\text { (ES) }\end{array}$ & $\begin{array}{l}\text { ES1 } \\
\text { ES2 } \\
\text { ES3 } \\
\text { ES4 }\end{array}$ & 66.674 & $\begin{array}{l}0.879 \\
0.617 \\
0.912 \\
0.826\end{array}$ & 0.709 & $\begin{array}{l}0.828 \\
0.460 \\
0.923 \\
0.770\end{array}$ & $\begin{array}{l}13.463^{* *} \\
7.235^{* *} \\
15.756^{* *} \\
12.984^{* *}\end{array}$ \\
\hline
\end{tabular}

Note: * significance level of $\mathrm{p}<0.05 ; * *$ significance level of $\mathrm{p}<0.01$ 
their attitude that safety and cooperation with society negatively influences the increase in business results. These results prove general hypotheses of this study and show that the criteria of the EFQM excellence model have positive implications on the satisfaction and loyalty of employees in the banking sector in Serbia.

The results of the obtained structural model are shown in Figure 2. Due to the clarity, only the values of path coefficients with significance levels and $t$ - values and the coefficients of determination $\mathrm{R}^{2}$ are shown. Presented results show that leadership has a positive influence on policy and strategy $(b=0.99, t=12.66, p<0.001)$, development of the human resources $(b=0.82, t=10.94$, $\mathrm{p}<0.001)$ and on the process management $(b=0.75, t=11.89, p<0.001)$. The policy and strategy predictor positively affects client relationships $(b=0.69, t=8.99, p<0.01)$, the relationship with suppliers $(b=0.72, t=9: 21$, $p<0.01)$ and the safety and society $(b=0.69$, $\mathrm{t}=9.17, \mathrm{p}<0.01)$. The business result is positively affected by the human resources $(b=0.50, \quad t=13.40, \quad p<0.01), \quad$ process management $(b=0.62, t=3.8, p<0.01)$, client relationships $\quad(b=0.67, \quad t=9.00 \quad p<0.01)$ relationships with suppliers $(b=0.59, t=9.23$, $\mathrm{p}<0.01$ ), while the security and society does not have a positive impact as well as statistical significance $(b=-0.08, t=-1.22$, no statistical significance). Business result positively effects employee satisfaction $(b=0.58, t=4.61, p<0.001)$. The employee satisfaction has a positive impact on the employee loyalty $(b=0.48, t=4.38, p<0.001)$. The results of the structural analysis indicate the strength of prediction for most variables in the model. The mean value of described variances of the included latent variables in the model is $55.91 \%$, which can be considered, compared to the results of similar studies, as very satisfactory results (Tari et al., 2007; Molina et al., 2007; AlShobaki et al., 2010).

In the defined structural model the first level of influence is expressed through the influence of leadership, defined by a hypothesis $\mathrm{H}_{1 \mathrm{a}}, \mathrm{H}_{1 \mathrm{~b}}$ and $\mathrm{H}_{1 \mathrm{c}}$, on dependent predictors and has nearly the same level of impact (b - values: 0.82, 0.99, 0.75, respectively). In the second level of the defined model the influence of the policy and strategy on the dependent predictors is defined by hypotheses $\mathrm{H}_{2 \mathrm{a}}, \mathrm{H}_{2 \mathrm{~b}}$ and $\mathrm{H}_{2 \mathrm{c}}$ and has nearly the same level of correlation ( $\mathrm{b}$ values: $0.69,0.72,0.69$, respectively). The third level of influence is defined in the model through the impact of predictors on the business result through hypotheses, $\mathrm{H}_{3}$,

Table 3. Summaries fitting indicators values of the conceptual structural model

\begin{tabular}{|l|c|c|}
\hline $\begin{array}{l}\text { Indicators of the } \\
\text { fitting statistics }\end{array}$ & $\begin{array}{l}\text { Obtained values in } \\
\text { the model }\end{array}$ & $\begin{array}{l}\text { Recommended } \\
\text { values }\end{array}$ \\
\hline $\mathbf{X}^{2} /$ d.f. & $1683.63 / 806=2.08$ & $<3.0$ \\
\hline RMSEA & 0.097 & $0.08-1.0$ \\
\hline GFI & 0.66 & $>0.9$ \\
\hline AGFI & 0.62 & $>0.9$ \\
\hline NFI & 0.91 & $>0.9$ \\
\hline NNFI & 0.93 & $>0.9$ \\
\hline CFI & 0.94 & $>0.9$ \\
\hline IFI & 0.94 & $>0.9$ \\
\hline RFI & 0.91 & $>0.9$ \\
\hline
\end{tabular}


$\mathrm{H}_{4}, \mathrm{H}_{5}, \quad \mathrm{H}_{6}$ and $\mathrm{H}_{7}$, and also has loyalty of employees in the banking sector in approximately the same level of correlation (b - values: $0.50,0.67,0.59,-0.08,0.62$, respectively). In the defined model the hypothesis $\mathrm{H}_{6}$ is not confirmed $(\mathrm{b}=-0.08, \mathrm{t}=$ -1.22 , not statistically significant). In the fourth level of the model the business result has the same level of strength of the relationship with the satisfaction of employees $\mathrm{H}_{8}(b=0.58)$ as the employees satisfaction on their loyalty $\mathrm{H}_{9}(\mathrm{~b}=0.48)$. The mean value of the correlation in the first level of the model has a value of $0.85,0.70$ in the second level, 0.59 in the third level and 0.49 in the fourth level. The results indicate that through the defined model the strength of the correlation weakens in the direction of the defined hypotheses.

\section{CONCLUSION}

Relationship of the EFQM excellence model criteria with the satisfaction and Serbia was investigated in this paper. Defined structural model shows that all the criteria that define the EFQM excellence model have a positive impact on satisfaction and employee loyalty. The leadership has a dominant influence, which directs almost all activities in the banking sector in Serbia. Working conditions in the banks are above average because they implemented working standards from the central banks in countries with developed economies. On the other hand, due to underdeveloped corporate social responsibility of these banks, their employees do not experience positively the cooperation of their banks with the community. Therefore, the security and society is not perceived by employees as a stimulus to business results.

The authors of this paper do believe that in the future it will be important to investigate the structural characteristics of the implementation of the EFQM excellence model and TQM practices in the relationship

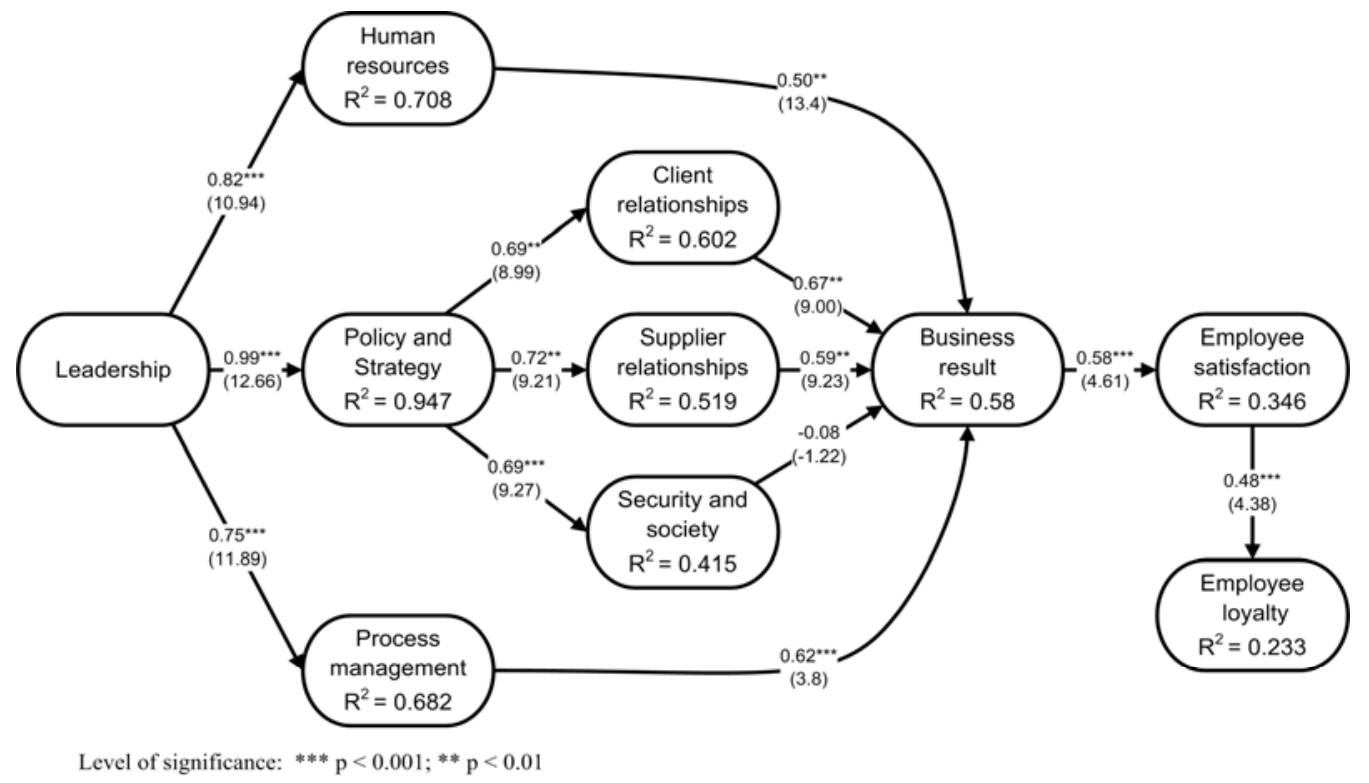

Figure 2. Structural model of some of the EFQM model of excellence criteria impact on the employee satisfaction and loyalty in the banking sector in Serbia (t-values in parenthesis) 
of the banking sector with the business sector and citizens, under the conditions of the transitional economy. The main objective is to find the dominant parameters influencing the stability of banks operations in order to create the necessary preconditions for initiating the need for the development of the motivational factors of higher hierarchical level than the existing.

On the other hand, underdeveloped corporate social responsibility of the banking system, in the conditions of transition economy, can be improved by developing teamwork and motivational factors of the higher level within the employees. This research should improve understanding of these issues and to initiate necessary changes.

\section{References}

Al-Shobaki, S.D., Fouad, R.H., \& AlBashir, A. (2010). The implementation of total quality management (TQM) for the banking sector in Jordan. Jordan Journal of Mechanical and Industrial Engineering, 4(2): 304-313.

Al-Zoubi, M.T. (2012). Generating benchmarking indicators for employee job satisfaction. Total Quality Management \& Business Excellence, 23(1): 27-44.

Balbastre-Benavent, F., \& Canet-Giner, M.T. (2011). The strategy formation process in the EFQM Excellence Model: a critical review and new perspectives. Total Quality Management \& Business Excellence, 22(7): 727-742.

\title{
МОДЕЛОВАЊЕ УТИЦАЈА “ЕЕQМ" КРИТЕРИЈУМА НА САТИСФАКЦИЈУ И ЛОЈАЛНОСТ ЗАПОСЛЕНИХ У ТРАНЗИЦИОНОЈ ЕКОНОМИЈИ: СТУДИЈА БАНКАРСКОГ СЕКТОРА У СРБИЈИ
}

\author{
Марија Савић, Предраг Ђорђевић, Ђорђе Николић, \\ Иван Михајловић и Живан Живковић
}

\begin{abstract}
Абстракт
У раду се презентују резултати емпиријског истраживања утицаја неких критеријума "EFQM" модела изврсности на сатисфакцију и лојалност запослених у банкарском сектору Србије. Све хипотезе у дефинисаном моделу су доказане статистичким вредновањем емпиријских резултата, осим хипотезе позитивног утицаја односа организације према сигурности и друштву на пословни резултат, што чини специфичност транзиционих економских услова у којима функционише проучавани банкарски сектор. Статистичка обрада је вршена коришћењем ЛИСРЕЛ в.16 софтверског пакета где су дефинисане статистичке значајности истраживаног скупа заједно са $b$ и $t$ вредностима дефинисаних путања у дефинисаном моделу. Истраживања су показала да критеријуми "EFQM" модела изврсности могу бити од користи за развој и унапређење функционисања банкарског сектора у Србији и изградње TQM праксе.
\end{abstract}

Кључне речи: "EFQM" модел, критеријуми, банке, сатисфакиија запослених, лојалност запослених, ЛИСРЕЛ 
Beikzard, J., Totakhaneh, J.M., \& Maleki, S.G. (2012). An empirical study on empowering private bank workers using EFQM. Management Science Letters, 2: 321-328.

Campatelli, G., Citti, P., \& Meneghin, A. (2011). Development of a simplified approach based on the EFQM model and Six Sigma for the implementation of TQM principles in a university administration. Total Quality Management \& Business Excellence, 22(7): 691-704.

Candido, C.J.F., \& Santos, S.P. (2011). Is TQM more difficult to implement than other transformational strategies? Total Quality Management \& Business Excellence, 22(11): 1139-1164.

Chang, C.C., Chiu, C.M., \& Cvhen, C.A. (2010). The effect of TQM practices on employee satisfaction and loyalty in government. Total Quality Management and Business Excellence, 21(12): 1299-1314.

Chen, R.F., Hsaio, J.L., \& Hwang, H.G. (2012). Measuring customer satisfaction of Internet banking in Taiwan: scale development and validation. Total Quality Management \& Business Excellence, 23(78): 749-767.

Corbett, C., Montes-Sancho, M., \& Kirsch, D. (2005). The financial impact of ISO 9000 certification: an empirical analysis. Management Sciences, 51(7): 1046-1059.

Cronbach, J.I. (1951). Coefficient alpha and the internal structure in tests. Psychometrika, 16: 297-334.

Doeleman, H. J., ten Have, S., \& Ahaus, K. (2012). The moderating role of leadership in the relationship between management control and business excellence. Total Quality Management \& Business Excellence, 23(5-6): 591-611.

EFQM. (2005). The EFQM excellence model criteria. Retrieved January 5 2006, Available from: http.// www.efqm.org/DEfault.aspx?tabid=40.

Heras-Saizarbitoria, I., Marimon, F., \& Casadacus, M. (2012). An empirical study of the relationships within the categories of the EFQM model. Total Quality Management \& Business Excellence, 23(5-6): 523-540.

Ho, R. (2006). Handbook of Univariate and Multivariate Data Analysis and Interpretation with SPSS. Taylor \& Francis Group, LLC, Boca Raton.

Ishaq, M.I. (2012). Service Quality, Perceived Value, Corporate Image and Customer Loyalty in Telecommunication Sector of Pakistan. Serbian Journal of Management, 7(1): 25-36.

Kaynak, H. (2003). The relationship between total quality management practices and their effects on firm performance. Journal of Operations Management: 21(4), 405-435.

Lam, S.Y., Lee, V.H., Ooi, K.B., \& Lin, B. (2011). The relationship between TQM, learning orientation and market performance in service organisations: an empirical analysis. Total Quality Management \& Business Excellence, 22(12): 1277-1297.

Latham, G.P., \& Ernst, C.T. (2006). Keys to motivating tomorrow's workforce. Human Resource Management Journal, 16: 181-198.

Lusar, J.C.B., Tena, A.B.E., Puig, V.R., \& Martin, I.B. (2009). An empirical assessment of the EFQM excellence model: evaluation as a TQM framework relative to the MBNQA model. Journal of Operations Management, 27: 1-22.

Mak, B.L., \& Sockel, H. (2001). A confirmatory factor analysis of IS employee motivation and satisfaction. Information \& Management, 38: 265-276.

Marimon, F., Yaya, L.H.P., \& Casadesus Fa, M. (2012). Impact of e-Quality and 
service recovery on loyalty: A study of ebanking in Spain. Total Quality Management \& Business Excellence, 23(7-8): 769-787.

Maslow, A. (1943). A Theory of Human Motivation. Psychological review, 50: 370396.

Molina, M.L., Montes-Lorens, J., \& RuizMoreno, A. (2007). Relationship between quality management practices and knowledge transfer. Journal of Operations Management, 25: 682-701.

Omachonu, V.K., \& Ross, J.E. (2004). Principles of total quality. Third edition, CRC Press, New York.

Safari, H., Abdollahi, B., \& Ghasemi, R. (2012). Canonical correlation analysis between people criterion and people results criterion in EFQM model. Total Quality Management \& Business Excellence, 23(56): 541-545.

Sheng-Hsun, H. (2007). Human capital, organizational learning, network resources and organizational innovations. Total Quality Management and Business Excellence, 18(9): 983-998.

Soltani, I., LI, P., \& Gharneh, N. (2005). Breaking through barriers to TQM effectiveness: lack of commitment of upper level management. Total Quality Management and Business Excellence, 16(89): 1009-1021.

Spasojević-Brkić, V., Putnik, G., (2013). User evaluation of the interfaces for the remote control of manufacturing systems. Serbian Journal of Management, 8(2): 201212.

Tari, J.J., Molina, J.F., \& Castejon, J.L. (2007). The relationship between quality management practices and their effects on quality outcomes. European Journal of Operational Research, 183: 483-501.

Tutuncu, O., \& Kucukusta, D. (2007). Relationship between organizational commitment and EFQM business excellence model: A study on Turkish quality award winners. Total Quality Management and Business Excellence, 18(10): 1083-1096.

van Donk, D.P., \& van der Vaart, T. (2005). A case of shared resources, uncertainty and supply chain integration in the process industry. International Journal of Production Economics, 96(1): 97-108.

Zelnik, M., Maletič, M., \& Gomiščrk, B. (2012). Quality management systems as a link between management and employees. Total Quality Management \& Business Excellence, 23(1): 45-62. 


\section{APPENDIX A: QUESTIONNAIRE}

\section{Leadership}

1. Top-level managers of the Bank take responsibility for the quality

2. Bank management personally takes the lead in providing and improving the quality

3. Top management of our Bank encourages employees in performing their tasks

4. Managers allow employees to make independent decisions

5. Managers actively refer employees to obligations towards quality

\section{Policy and Strategy}

1. Develop and implementation of the strategies and plans is based on customer requirements and capabilities of the bank

2. The management sets objectives for all employees

3. Evaluation of results is done by comparing results with plans with the aim to improve them

4. Management involves employees in setting of objectives and plans

5. Management transfers strategy and objectives to all staff

\section{Human Resources}

1. Management is trained in quality principles

$\begin{array}{lllll}1 & 2 & 3 & 4 & 5\end{array}$

2. Employees are trained in quality principles

$\begin{array}{lllll}1 & 2 & 3 & 4 & 5\end{array}$

3. Employees are trained in teamwork

$\begin{array}{lllll}1 & 2 & 3 & 4 & 5\end{array}$

4. The employees recognize the value of performance in order to support quality programs

$\begin{array}{lllll}1 & 2 & 3 & 4 & 5\end{array}$

5. Communication among all employees is moving from the bottom up, top-down and horizontally

$\begin{array}{lllll}1 & 2 & 3 & 4 & 5\end{array}$

\section{Managing the Process}

1. This Bank is implementing continuous control and improvement of key processes

$\begin{array}{lllll}1 & 2 & 3 & 4 & 5\end{array}$

2. Prevention of deficiencies in products/services is a common practice in this Bank

$\begin{array}{lllll}1 & 2 & 3 & 4 & 5\end{array}$

3. The processes used in this Bank include the measurement of quality

$\begin{array}{lllll}1 & 2 & 3 & 4 & 5\end{array}$

4. Employees are involved in the evaluation of knowledge in the various processes which are implemented in the Bank 


\section{Relationships with clients}

1. This Bank analyzes the information obtained from clients to measure their satisfaction

$\begin{array}{lllll}1 & 2 & 3 & 4 & 5\end{array}$

2. Customer satisfaction shows visible improvement

$\begin{array}{lllll}1 & 2 & 3 & 4 & 5\end{array}$

3. Our clients receive quality feedback through improved performance

$\begin{array}{lllll}1 & 2 & 3 & 4 & 5\end{array}$

4. The company applies the process of listening to and resolving customer complaints

\section{Relationships with suppliers}

1. We strive to establish long term relationships with suppliers

$\begin{array}{lllll}1 & 2 & 3 & 4 & 5\end{array}$

2. Our suppliers are actively involved in new product development process

$\begin{array}{lllll}1 & 2 & 3 & 4 & 5\end{array}$

3. Quality is the primary criterion in selecting suppliers

\section{Security and Society}

1. Regulations were developed in order to reduce and prevent health and safety risks of the bank

2. In this Bank regulations were developed for the protection of the environment

3. This Bank takes a sufficiently active role in community development

\section{Business Results}

1. Our financial results are remarkable

$\begin{array}{lllll}1 & 2 & 3 & 4 & 5\end{array}$

2. Our quality program increases our revenues

$\begin{array}{lllll}1 & 2 & 3 & 4 & 5\end{array}$

3. Our quality program increases our sales

$\begin{array}{lllll}1 & 2 & 3 & 4 & 5\end{array}$

4. Our quality program improves our competitive position

$\begin{array}{lllll}1 & 2 & 3 & 4 & 5\end{array}$

5. Our quality program generally improves our performance

\section{Satisfaction of employees}

1. I feel personal satisfaction when I do a good job

$\begin{array}{lllll}1 & 2 & 3 & 4 & 5\end{array}$

2. I am proud to tell people that I am a part of this Bank

$\begin{array}{lllll}1 & 2 & 3 & 4 & 5\end{array}$

3. For me this is the best organization where I have worked.

$\begin{array}{lllll}1 & 2 & 3 & 4 & 5\end{array}$

4. I would recommend this bank to friends if they are looking for a job. 
10. Loyalty of employees
1. I am prepared to invest considerable effort in order to contribute to the success of the Bank
$\begin{array}{lllll}1 & 2 & 3 & 4 & 5\end{array}$
2. I plan to build a career in this Bank
$\begin{array}{lllll}1 & 2 & 3 & 4 & 5\end{array}$
3. I care about the fate of this Bank
$\begin{array}{lllll}1 & 2 & 3 & 4 & 5\end{array}$
4. I am loyal to the Bank in a large extent.
$\begin{array}{lllll}1 & 2 & 3 & 4 & 5\end{array}$

To express an opinion of a complete disagreement circle 1, partial disagreement 2, neutral 3, partial agreement 4 and complete agreement 5. 